\title{
New Additions to the Jellyfish Fauna of the Sea of Marmara
}

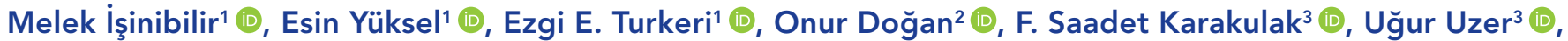 \\ Cem Dalyan ${ }^{4}$ (D), Giulia Furfaro 5 (1), Stefano Piraino ${ }^{5}$ (D)
}

Cite this article as: Isinibilir, M., Yuksel, E., Turkeri, E.E., Dogan, O., Karakulak, F.S., Uzer, U., Dalyan, C., Furfaro, G., \& Piraino, S. (2022). New Additions to the Jellyfish Fauna of the Sea of Marmara. Aquatic Sciences and Engineering, 37(1), 53-57.

\author{
ORCID IDs of the author: \\ M.I. 0000-0002-1200-6878; \\ E.Y. 0000-0002-1651-7229; \\ E.E.T. 0000-0003-2017-6137; \\ O.D. 0000-0002-5576-2331; \\ F.S.K. 0000-0002-6053-5256 \\ U.U. 0000-0002-7038-6469; \\ C.D. 0000-0002-7386-5641; \\ G.F. 0000-0001-8184-2266; \\ S.P. $0000-0002-8752-9390$ \\ Department of Marine Biology, Faculty \\ of Aquatic Sciences, Istanbul University, \\ Istanbul, Turkey \\ 2Institute of Graduate Studies in Sciences, \\ Istanbul University, Istanbul, Turkey \\ ${ }^{3}$ Department of Fisheries Technology \\ and Management, Faculty of Aquatic \\ Sciences, Istanbul University \\ Istanbul, Turkey \\ ${ }^{4}$ Department of Biology, Science Faculty, \\ Istanbul University, Istanbul, Turkey \\ ${ }^{5}$ Dipartimento di Scienze e Tecnologie \\ Biologiche ed Ambientali, Stazione di \\ Biologia Marina, Università del Salento, \\ Lecce, Italy \\ Submitted: \\ 11.08.2021 \\ Revision Requested: \\ 11.11.2021 \\ Last Revision Received: \\ 19.11.2021 \\ Accepted: \\ 22.11.2021 \\ Online Published: \\ 31.12.2021 \\ Correspondence: \\ Melek Isinibilir \\ E-mail: \\ melekis@istanbul.edu.tr
}

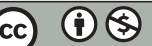

\begin{abstract}
This manuscript reports on four new jellyfish species in the Sea of Marmara (Turkey) (the scyphozoans Mawia benovici and Drymonema dalmatinum, hydrozoan Aequorea forskalea, and thaliacean Salpa maxima) based on plankton collections made in the years 2019-2021. This is the first record of Mawia benovici in both Turkish coastal areas and the Sea of Marmara. The jellyfish that was previously recorded as Drymonema sp. in the repetition Sea of Marmara was identified at the species level as $D$. dalmatinum. Furthermore, their possible introduction pathways are briefly discussed here.
\end{abstract}

Keywords: Aequorea forskalea, Drymonema dalmatinum, Mawia benovici, Salpa maxima, the Sea of Marmara

\section{INTRODUCTION}

The Sea of Marmara is an inland sea that connects the Mediterranean and the Black Seas via the Çanakkale and Istanbul Straits, respectively, and acts as a biogeographical crossroad that includes elements of both Black Sea and Mediterranean Sea biodiversity. The Sea of Marmara is characterized by a permanent, two-layered water system because of the distinct characteristics of two adjacent basins. The upper layer (on average, <25 $\mathrm{m}$ depth) consists of brackish Black Sea water ( 18 psu) while the lower layer (below the halocline) consists of saline Mediterranean water ( 38 psu) (Beşiktepe, Sur, Özsoy, Latif, \& Oğuz, 1994). As a consequence of its geographical and hydrographical properties, it forms a barrier and/or a corridor depending on species' potential to acclimatize (Beşiktepe et al., 1994; Ozturk \& Ozturk, 1996).

Recent studies of new species demonstrated that the number of jellyfish in the Sea of Marmara has been rising (Isinibilir, Yilmaz, \& Demirel, 2015; Isinibilir, Yüksel, \& Dalyan, 2020; Yilmaz,
Isinibilir, Vardar, \& Dursun, 2017). Mnemiopsis leidyi caused major harm to the ecosystem after it expanded its niche to the Sea of Marmara following its introduction to the Black Sea at the end of 1980 (Isinibilir, Tarkan, \& Kideys, 2004; Shiganova, 1998). Ever since, non-indigenous jellyfish species such as Chrysaora hysoscella, Liriope tetraphylla, Aequorea vitrina, Cotylorhiza tuberculata, and others have been introduced to the basin (Inanmaz, Bekbolet, \& Kıdeyş, 2002; Isinibilir, Yilmaz, \& Piraino, 2010; İşinibilir et al., 2020; Yilmaz et al., 2017). In general, jellyfish are important consumers of zooplankton in pelagic ecosystems, although their ecological role is still poorly understood (Lucas, Gelcich, \& Uye, 2014). This report aims to contribute to the knowledge of the changing diversity of jellyfish in the Sea of Marmara by presenting the first records of four gelatinous taxa belonging to the classes Hydrozoa, Scyphozoa, and Thaliacea.

\section{MATERIALS AND METHODS}

The samples of Aequorea forskalea and Mawia benovici were collected through deep trawling 
during cruises by R/V Yunus-S in the southern and northeastern part of the Sea of Marmara during July 2019 and June 2020. The samples of Salpa maxima were collected through scuba diving, with the collaboration of local divers, in the vicinity of the Princes' Islands in the Sea of Marmara in November 2020. The sample of Drymonema dalmatinum from the Maltepe coast was caught in large plastic buckets with the help of local fishermen and transported to the faculty laboratory in January 2021. The location of the sampling stations is shown in Figure 1. Specimens were fixed in $96 \%$ ethanol solution for the subsequent analysis. Identification of specimens was carried out under stereomicroscope and light microscope in the laboratory. Samples were taken from all species for molecular analysis and stored in the faculty laboratory for further analysis. In this report, DNA barcoding from a single scyphozoan species, namely Mawia benovici, was carried out.

The species identity of specimens of Mawia benovici was also confirmed by a DNA-barcoding approach using the cytochrome oxidase subunit I (COI) mitochondrial marker. DNA was extracted using Qiagen DNeasy Blood \& Tissue Kits, according to the manufacturer's handbook. Partial COI sequences were amplified by polymerase chain reaction (PCR), setting the parameters as in Furfaro, Oliverio, and Mariottini (2017) (PCR profile: 5 min denaturation step at $94^{\circ} \mathrm{C} ; 35$ cycles of $94^{\circ} \mathrm{C} / 30 \mathrm{~s}, 48^{\circ} \mathrm{C} / 60 \mathrm{~s}, 72^{\circ} \mathrm{C} / 60$ $\mathrm{s} ; 7 \mathrm{~min}$. final extension at $\left.72^{\circ} \mathrm{C}\right)$, using the universal primers LCO1490 and HCO2198 (Folmer, Black, Hoeh, Lutz, \& Vrijenhoek, 1994). Amplicons were sequenced by the European Division of Macrogen Inc. (Amsterdam, The Netherlands). A BLASTN (Altschul, Gish, Miller, Myers, \& Lipman, 1990) search was conducted to rule out sample contamination. Sequence homology was investigated by comparing newly produced sequences with the ones already available in GenBank.

\section{RESULTS AND DISCUSSION}

In the present study, three jellyfish species (one scyphozoan, one hydrozoan, and one thaliacean) were reported for the first time and the genus Drymonema was identified at the species level in the Sea of Marmara (Figure 1). Bouillon et al. (2004), Van Soest (1974), and Piraino et al. (2014) have been used as the primary sources for taxonomic identification and description of characteristics of the species. Notes related to their spatial distribution are reported below.

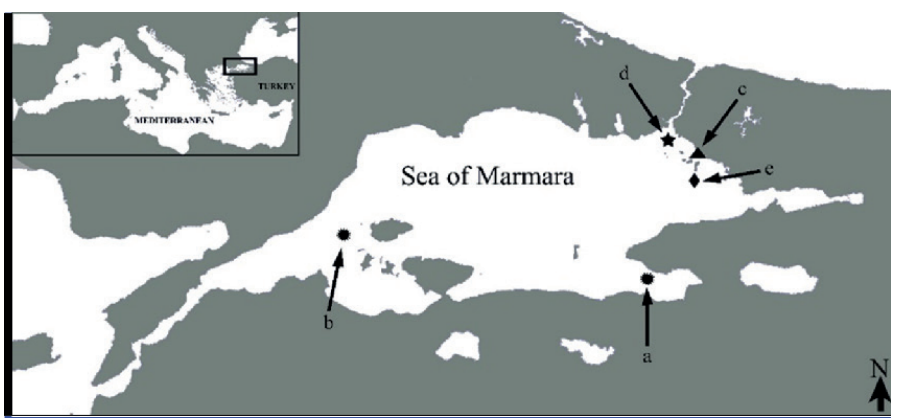

Figure 1. Map of the Sea of Marmara and sampling locations of the specimens ( $a, b$ : Mawia benovici; c: Drymonema dalmatinum; d: Aequorea forskalea; e: Salpa maxima).
Class: Scyphozoa

Subclass: Discomedusae

Order: Semaeostomeae

Family: Pelagiidae

Genus: Mawia

Mawia benovici (Piraino, Aglieri, Scorrano \& Boero, 2014)

Mawia benovici specimens were collected as bycatch during trawl surveys from $71 \mathrm{~m}$ (st. MD22, Figure 1, Station a) and $108 \mathrm{~m}$ (st. MD13A, Figure 1, Station b). In the survey, four living specimens were collected. The first specimen was observed on November 2, 2019 at the MD22 station (Figure 1, Station a) and the other three specimens on November 3, 2019 at the MD13A station (Figure 1, Station b). The umbrella diameters ranged from 60 to $70 \mathrm{~mm}$ and were hemispherical to somewhat flattened with a thin transparent mesogleal layer. The exumbrella was yellow ochre in color and was covered by conspicuous cnidocyst warts; eight marginal tentacles; 16 marginal lappets; 16 unbranched, simple radial septa terminating between sense organs and tentacles, as in the genus Pelagia; and 8 tentacular and 8 rhopalial separate pouches. The manubrium had a whitish, transparent, very short mouth tube and sharp, long, delicate mouth arms. The gonads were milky white in color, horseshoe shaped, and developed on the subumbrellar surface (Figure 2A, B).

Mawia benovici (formerly described Pelagia benovici) was recorded in several locations, such as the northern Adriatic (Trieste to Chioggia (Venice)), the Central Adriatic (near Numana, Ancona), and the Ionian Sea (Igoumenitsa Bay) (Avian, Ramšak, Tirelli, D’ambra, \& Malej, 2016; Chartosia et al., 2018; Piraino et al., 2014) in the Mediterranean. However, it has not been recorded in the eastern part of the Mediterranean so far. This species, which

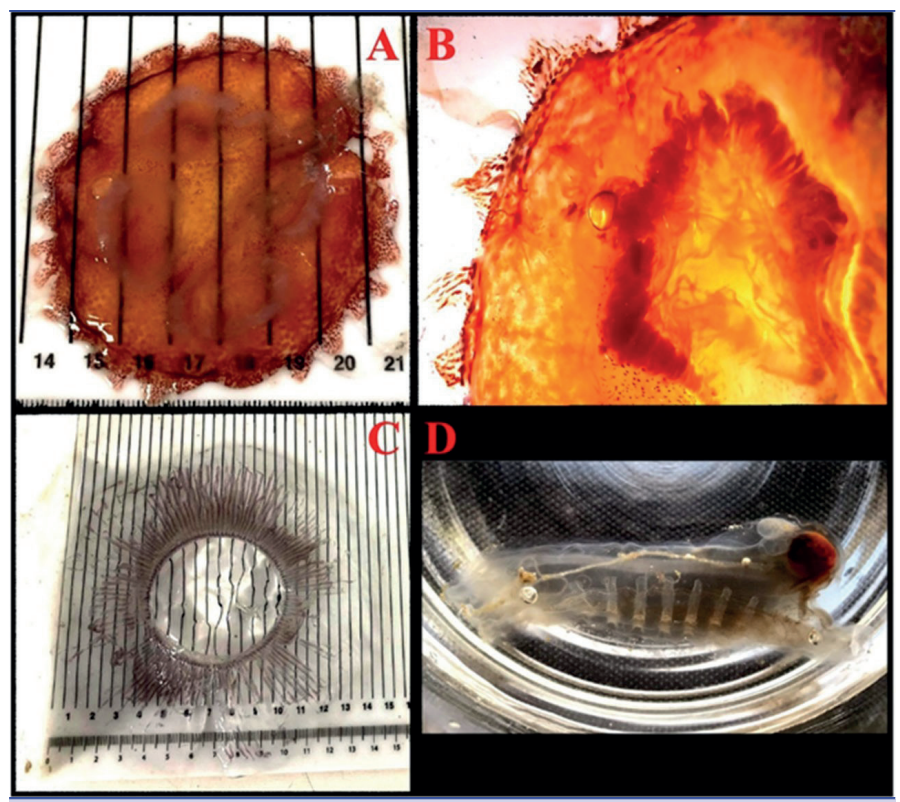

Figure 2. Photographs of the new jellyfish records in the Sea of Marmara. (A) and (B) Mawia benovici; (C) Aequorea forskalea; (D) Salpa maxima. 
is assumed to be non-indigenous to the Mediterranean, has also been recorded on the coast of Senegal (Bayha, Collins, \& Gaffney, 2017). According to Bayha et al. 2017, the species which was found in the Mediterranean might have originated from the western coast of Africa and been introduced as a result of commercial shipping or fishing. As suggested by Piraino et al. (2014), this species was probably introduced into the Adriatic Sea by ship translocation through ballast waters.

Little information is still available concerning the establishment of $M$. benovici in the Adriatic Sea and, more generally, in the Mediterranean basin. DNA sequences (GenBank COI accession numbers OU193096 and OU193097) were obtained from two specimens collected at the MD13A station (Figure1, Station b). DNA barcoding analysis revealed $100 \%$ of homology with $\mathrm{COI}$ sequences already present in GenBank and ascribed to Mawia benovici (in GenBank as Pelagia benovici), definitively confirming that the two collected specimens belong to this rare species. As a result, this is the first record of the species in both Turkish coastal areas and the Sea of Marmara.

Class: Scyphozoa

Subclass: Discomedusae

Order: Semaeostomeae

Family: Cyaneidae

Genus: Drymonema

\section{Drymonema dalmatinum Haeckel, 1880}

The large-sized semaeostome jellyfish Drymonema dalmatinum has recently been reported in various regions of the Mediterranean, especially the Adriatic Sea. Earlier records of Drymonema dalmatinum (the only Drymonema species in the Mediterranean Sea) go back to 1892 in the Gulf of Izmir (Antipa, 1892). This genus was recorded without species identification for the first time in the Sea of Marmara as Drymonema sp. in 2020 (Öztürk, 2020). One year later, the occurrence of $D$. dalmatinum was reported in a fishermen's observation on January 18, 2021 on the Maltepe coast in the northeastern Sea of Marmara (Figure 1, Station c). The jellyfish was found near the sea surface, with a bell diameter of approximate $120 \mathrm{~cm}$. The orientation of the umbrella was upwards; the bell was milkfish white, shield-shaped, and flatly rounded with a thicker central part (Figure 3). The numerous tentacles were longer

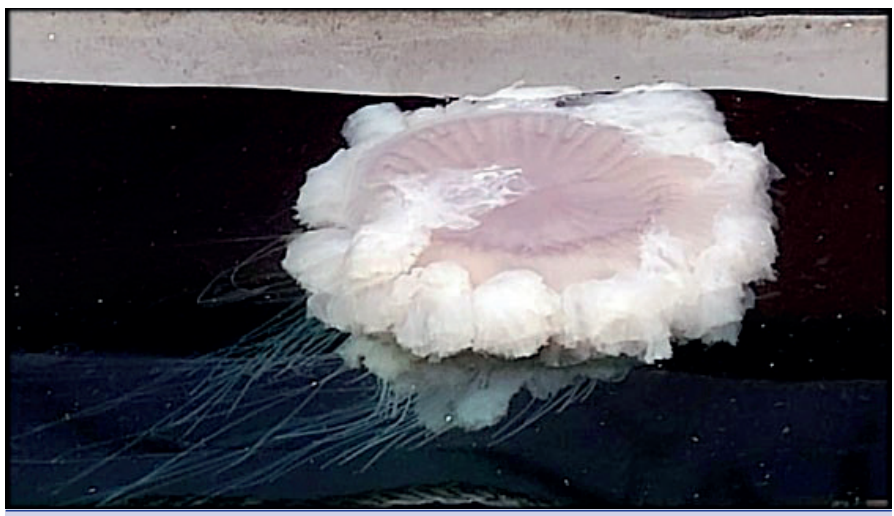

Figure 3. Drymonema dalmatinum in the Sea of Marmara. than the diameter of the bell and of unequal lengths and thickness, and were not grouped in separated clusters.

Class: Hydrozoa

Subclass: Hydroidolina

Order: Leptothecata

Family: Aequoreidae

Genus: Aequorea

\section{Aequorea forskalea Péron \& Lesueur, 1810}

Although Aequorea forskalea is a common and abundant hydromedusan species in the Mediterranean (Bouillon et al., 2004) and has been recorded in Turkish coastal areas (Gürlek, Yağlığlu, Ergüden, \& Turan, 2013; Topcu, Martell, \& Isinibilir, 2017), it was not encountered in zooplankton samples from the Sea of Marmara before the present study. Two specimens were first sampled in June 2020 from the lower layer of the northeastern Sea of Marmara (off the coast of Tuzla; sampling depth 80m) (Figure 1, Station d). The umbrella was large, up to $140 \mathrm{~mm}$ wide, saucer shaped, and thick in the center. It had 120 simple and dark colored radial canals and 120 tentacles. The medusa had tubeshaped tentacle bulbs (Figure 2C). In the coastal waters of Turkey, four species of Aequorea have been reported: Aequorea forskalea (Péron \& Lesueur, 1810), Aequorea globosa (Eschscholtz, 1829), Aequorea pensilis, and Aequorea vitrina (Gosse, 1853) (Gürlek et al., 2013; Onmuş, Bakir, \& Katağan, 2016; Topcu et al., 2017; Turan, Gürlek, Yağlığlu, \& Seyhan, 2011; Yilmaz et al., 2017). In the Mediterranean, A. forskalea is distributed in the eastern and western Mediterranean, including the Adriatic and Aegean Seas (Bouillon et al., 2004; Topcu et al., 2017; Yilmaz \& Isinibilir, 2016). So far, no records of $A$. forskalea were available from the Sea of Marmara (Yilmaz et al., 2017).

\section{Class: Thaliacea}

Order: Salpida

Family: Salpidae

Subfamily: Salpinae

Genus: Salpa

\section{Salpa maxima Forskål, 1775}

Although Salpa maxima is known as a common species in the Mediterranean Sea (Durgham \& Ikhtiyar, 2013; Mutlu, 2005; Peinert \& Miquel, 1994; Topcu et al., 2017), it had not been recorded in the Sea of Marmara before. Many colonies of S. maxima have been observed and one of them was sampled through scuba diving, with the collaboration of local divers in the vicinity of the Princes' Islands in the Sea of Marmara (Figure 1, Station e). The solitary forms have an $8 \mathrm{~cm}$ length with a smooth body with shallow longitudinal depressions. Because of its extreme thickness, the appearance is not completely transparent. There are a total of nine muscles along the dorsal side of the body. The colonies were impressively long (Figure 4), reaching up to $2 \mathrm{~m}$ in length, and were seen by fishermen and scuba divers.

Because of its geographical and hydrological characteristics, the Sea of Marmara is a vulnerable ecosystem. This eutrophic sea is 


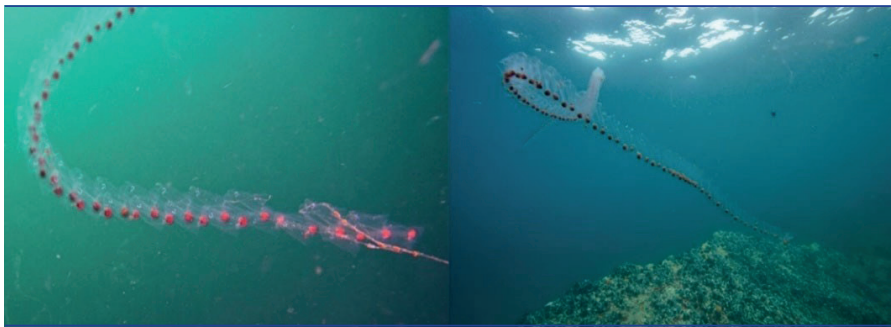

Figure 4. Chains of Salpa maxima in the waters of the Princes' Islands (Photograph: İsmail Cem Odabaşı).

Turkey's second commercially important fishing ground (Yılmaz, Akay, \& Gümüş, 2008). As a result, any increase in jellyfish populations could have negative consequences for fisheries (Isinibilir \& Yilmaz, 2016). With its unique properties, the Sea of Marmara also serves as a barrier and/or transitional acclimatization zone for biological organisms. Shipping and currents are two potential routes for jellyfish introduction in this Sea. Salps can feed on all sizes of phytoplankton, from viruses to protists, thus being in direct competition with crustaceans (Bone, 1998). Therefore, bloom of Salpa maxima may cause depletion of phytoplankton and adversely impact the food web (Boero, 2013). The presence of Aequorea forskalea in Turkish coastal waters may be related to its migration from the western Mediterranean, where it is common. Aequorea forskalea prey mainly on copepods and amphipods (Zavolokin, Glebov, \& Kosenok, 2008), hence the bloom of this jellyfish may threaten commercially important fish stocks through food competition.

Mawia benovici could have been transported via ballast waters from the Mediterranean Sea or introduced through the lower layer flow of the Çanakkale Strait, because it already existed in the Mediterranean Sea. The life cycle of this species is still unknown. However, the medusa can reproduce by fission, a common asexual reproduction method in cnidarians (Chartosia et al., 2018). For this reason, the possible effect of its invasion is still unclear, and monitoring is necessary to understand the ecological consequences.

On the other hand, the Sea of Marmara, besides acting as a transition zone between the Black Sea and the Mediterranean, has important ports and most of them are located in the northeastern part. All species except $M$. benovici were recorded for the first time in the vicinity of Istanbul, thus suggesting the arrival of these species through ships' ballast waters. However, higher prey availability in the upper layer of the northeastern part of the Sea of Marmara may also have been an important factor in the availability of this species.

\section{CONCLUSION}

Recent studies have demonstrated that the environmental changes caused by intensive anthropogenic activity (e.g. eutrophication, overfishing, translocations, habitat modification, coastal development, etc.) and climate change due to global warming increase jellyfish blooms all over the world (Dong, Liu, \& Keesing, 2010; Purcell, Uye, \& Lo, 2007; Richardson, Bakun, Hays, \& Gibbons, 2009). Overfishing may also result in increased jellyfish populations due to the removal of jellyfish predators and competitors.
As the Sea of Marmara has a long history of overfishing (Zengin \& Mutlu, 2000), the potential effects on jellyfish populations cannot be ignored. Other human activities can also influence jellyfish populations. Similar to the effects of eutrophication, increased coastal urban development may ultimately lead to more jellyfish due to an increase in prey and substrate for the establishment of their polyps (Brotz \& Pauly, 2012). Warning signs of ecological deterioration such as algae blooms, marine mucilage events, and jellyfish blooms have increased significantly in the Sea of Marmara in recent years. (Isinibilir, 2012; İşinibilir-Okyar, Üstün, \& Orun, 2015; Turkoglu, 2013; Yılmaz, 2014). In addition, the number of jellyfish species recorded from the Sea of Marmara increased in the last decades and is still increasing (Inanmaz et al., 2002; Isinibilir et al., 2010; Isinibilir et al., 2020; Yilmaz et al., 2017). The rise of new jellyfish species might represent a future threat for the region by switching available trophic resources from zooplankton to unfavorable jellyfish biomass, thus eventually affecting fisheries and triggering changes in the functioning of the pelagic food web. Intensive and continuous monitoring of the Sea of Marmara is recommended in order to obtain updated information and predict the ecological effects of jellyfish on marine coastal ecosystems.

Conflicts of interest: The authors have no conflicts of interest to declare.

Ethics committee approval: The authors declare that this study does not include any experiments with human or animal subjects.

\section{Funding: -}

Acknowledgements: This study was supported by the Ministry of Environment and Urbanization, TUBITAK-MRC (2018). "Integrated Marine Pollution Monitoring 2017-2019 Programme: 2019 The Sea of Marmara Report, TÜBITAK-MRC Press, Kocaeli." The authors thank the personnel of R/V Yunus-S and all fishermen who assisted in taking samples. The authors are also grateful to scuba divers İsmail Cem Odabaşı and Volkan Narcı for their valuable photographs and contribution.

Disclosure: No potential conflict of interest was reported by the authors.

\section{REFERENCES}

Altschul, S. F., Gish, W., Miller, W., Myers, E. W. \& Lipman, D. J. (1990). Basic local alignment search tool. J mol biol 215: 403-410. [CrossRef] Antipa, G. (1892). Eine neue Art von Drymonema. Jen. Z. Naturwissenschaften 27: 337-345 (in German).

Avian, M., Ramšak, A., Tirelli, V., D’ambra, I. \& Malej, A. (2016). Redescription of Pelagia benovici into a new jellyfish genus, Mawia, gen. nov., and its phylogenetic position within Pelagiidae (Cnidaria: Scyphozoa: Semaeostomeae). Invertebrate Systematics, 30(6), 523546. [CrossRef]

Bayha, K. M., Collins, A. G. \& Gaffney, P. M. (2017). Multigene phylogeny of the scyphozoan jellyfish family Pelagiidae reveals that the common US Atlantic sea nettle comprises two distinct species (Chrysaora quinquecirrha and C. chesapeakei). PeerJ, 5, e3863. [CrossRef]

Beşiktepe, Ş. T., Sur, H. I., Özsoy, E., Latif, M.A. \& Oğuz, T. et al. (1994). The circulation and hydrography of the Marmara Sea. Progress in Oceanography, 34(4), 285-334. [CrossRef] 
Boero, F. (2013). Review of jellyfish blooms in the Mediterranean and Black Sea. General Fisheries Commission for the Mediterranean. Studies and Reviews, (92), I.

Bone, Q. (1998). The biology of pelagic tunicates. Oxford: Oxford University Press.

Bouillon, J., Medel, M. D., Pagès, F., Gili, J. M. \& Boero, F. et al. (2004). Fauna of the Mediterranean hydrozoa. [CrossRef]

Brotz, L., \& Pauly, D. (2012). Jellyfish populations in the Mediterranean Sea. Acta Adriat, 53(2), 213-232.

Chartosia, N., Anastasiadis, D., Bazairi, H., Crocetta, F. \& Deidun, A. et al. (2018). New Mediterranean Biodiversity Records (July 2018). [CrossRef]

Dong, Z., Liu, D. \& Keesing, J. K. (2010). Jellyfish blooms in China: dominant species, causes and consequences. Marine pollution bulletin, 60(7), 954-963. [CrossRef]

Durgham, H. \& Ikhtiyar, S. (2013). First record of Salpa maxima Forskål, 1775 (Thaliacea: Salpidae) from the Mediterranean Coast of Lattakia (Syria). Mediterranean Marine Science, 14(2).

Folmer, O., Black, M., Hoeh, W., Lutz, R. \& Vrijenhoek, R. (1994). DNA primers for amplification of mitochondrial cytochrome c oxidase subunit I from diverse metazoan invertebrates. Mol Mar Biol Biotechnol. 3: 294-299.

Furfaro, G., Oliverio, M. \& Mariottini, P. (2017). The southernmost record of Felimida elegantula (Philippi, 1844) (Gastropoda: Nudibranchia). Marine Biodiversity, 47(2), 579-584. [CrossRef]

Gürlek, M., Yağlığlu, D., Ergüden, D. \& Turan, C. (2013). A new jellyfish species in the Turkish coastal waters-Aequorea forskalea Péron \& Lesueur, 1810 (Cnidaria: Hydrozoa). J Black Sea/Medit Environ, 19(3), 380-384.

Inanmaz, Ö. E., Bekbolet, M. \& Kıdeyş, A. E. (2002). A new scyphozoan species in the Sea ofMarmara: Chrysaora hysoscella (Linné, 1766). Oceanography of the Eastern Mediterranean and Black Sea. Ankara, Turkey: TÜBITAK, 857-859.

Isinbilir, M. \& Yılmaz, i. N. (2016). Jellyfish species of the Sea of Marmara. The Sea of, 390.

Isinibilir, M. (2012). The seasonal occurrence and abundance of gelatinous macrozooplankton in Izmit Bay (the northeastern Marmara Sea). Journal of Black Sea/Mediterranean Environment, 18(2), 155-176.

Isinibilir, M., Tarkan, A.N. \& Kideys, A. E. (2004). Decreased levels of the invasive ctenophore Mnemiopsis in the Marmara Sea in 2001. In Aquatic Invasions in the Black, Caspian, and Mediterranean Seas (pp. 155-165). Springer, Dordrecht.

Isinibilir, M., Yilmaz I. N. \& Demirel, N. (2015). New records of jellyfish species in the Marmara Sea. Italian Journal of Zoology, 82(3), 425429. [CrossRef]

Isinibilir, M., Yilmaz, I. N. \& Piraino, S. (2010). New contributions to the jellyfish fauna of the Marmara Sea. Italian Journal of zoology, 77(2), 179-185. [CrossRef]

Işsinibilir-Okyar, M., Üstün, F. \& Orun, D. A. (2015). Changes in abundance and community structure of the zooplankton population during the 2008 mucilage event in the northeastern Marmara Sea. Turkish Journal of Zoology, 39(1), 28-38. [CrossRef]

Isinibilir, M., Yüksel, E. \& Dalyan, C. (2020). First record of Cotylorhiza tuberculata (Macri, 1778) from the Sea of Marmara. Aquatic Sciences and Engineering, 36(1), 38-41. [CrossRef]

Lucas, C. H., Gelcich, S., \& Uye, S. I. (2014). Living with jellyfish: management and adaptation strategies. Jellyfish blooms, 129-150. [CrossRef]

Mutlu, E. (2005). A comparison of the contribution of zooplankton and nekton taxa to the near surface acoustic structure of three Turkish seas. Marine Ecology, 26(1), 17-32. [CrossRef]
Onmuş, O., Bakir, K. \& Katağan, T. (2016). On the occurrence of a new Aequorea species on the Turkish Aegean coast. J. Black Sea/ Mediterranean Environment, 22(3), 295-299.

Ozturk, B. \& Ozturk, A. A. (1996). On the biology of the Turkish straits system. Bull Inst Oceanogr, 17, 205-21.

Öztürk, I. D. (2020). The first record of Drymonema sp. from the Sea of Marmara, Turkey. Journal of the Black Sea/Medit Environ, 26(2), 231-237.

Peinert, R. \& Miquel, J. C. (1994). The significance of frontal processes for vertical particle fluxes: A case study in the Alboran Sea (SW Mediterranean Sea). Journal of Marine Systems, 5(3-5), 377-389. [CrossRef]

Piraino, S., Aglieri, G., Martell, L., Mazzoldi, C. \& Melli, V. et al. (2014). Pelagia benovici sp. nov.(Cnidaria, Scyphozoa): a new jellyfish in the Mediterranean Sea. Zootaxa, 3794(3), 455-468. [CrossRef]

Purcell, J. E., Uye, S. I. \& Lo, W. T. (2007). Anthropogenic causes of jellyfish blooms and their direct consequences for humans: a review. Marine Ecology Progress Series, 350, 153-174. [CrossRef]

Richardson, A. J., Bakun, A., Hays, G. C. \& Gibbons, M. J. (2009). The jellyfish joyride: causes, consequences and management responses to a more gelatinous future. Trends in ecology \& evolution, 24(6), 312-322. [CrossRef]

Shiganova, T. A. (1998). Invasion of the Black Sea by the ctenophore Mnemiopsis leidyi and recent changes in pelagic community structure. Fisheries Oceanography, 7(3-4), 305-310. [CrossRef]

Topcu, N., Martell, L. \& Isinibilir, M. (2017). A multispecific accumulation of gelatinous organisms in the central Aegean Sea as a case of biological evidence for unnoticed offshore events.

Turan, C., Gürlek, M., Yağlıoğlu, D. \& Seyhan, D. (2011). A new alien jellyfish species in the Mediterranean Sea-Aequorea globosa Eschscholtz, 1829 (Cnidaria: Hydrozoa). Journal of the Black Sea/ Mediterranean Environment, 17(3), 282-286.

Turkoglu, M. (2013). Red tides of the dinoflagellate Noctiluca scintillans associated with eutrophication in the Sea of Marmara (the Dardanelles, Turkey). Oceanologia, 55(3), 709-732. [CrossRef]

Van Soest, R. W. M. (1974). A revision of the genera Salpa Forskål, 1775, Pegea Savigny, 1816, and Ritteriella Metcalf, 1919 (Tunicata, Thaliacea). Beaufortia, 22(293), 153-191.

Yilmaz, I. N. (2014). Collapse of zooplankton stocks during Liriope tetraphylla (Hydromedusa) blooms and dense mucilaginous aggregations in a thermohaline stratified basin. Mar Ecol (in press). [CrossRef]

Yilmaz, I. N. \& Isinibilir, M. (2016). Zooplankton of the Sea of Marmara. In: Özsoy E, Çağatay MN, Balkıs N, Balkıs N, Öztürk B (eds) The sea of Marmara marine biodiversity, fisheries, conservation and governance. Turkish Marine Research Foundation (TUDAV), Istanbul, pp 376-389

Yilmaz, I. N., Isinibilir, M., Vardar, D. \& Dursun, F. (2017). First record of Aequorea vitrina Gosse, 1853 (Hydrozoa) from the Sea of Marmara: a potential invader for the Mediterranean Sea. Zoology in the Middle East, 63(2), 178-180. [CrossRef]

Yılmaz, S., Akay, Ş.A. \& Gümüş, E. (2008). Fisheries sector in Turkish economy and marketing of fishery products.

Zavolokin, A. V., Glebov, I. I. \& Kosenok, N. S. (2008). Distribution, quantitative composition, and feeding of jellyfish in the Western Bering Sea in summer and fall. Russian Journal of Marine Biology, 34(7), 461-467. [CrossRef]

Zengin, M. \& Mutlu, C. (2000). The recent state of the fisheries and suggestions related to the future of the stocks at the Marmara Sea. Marmara Denizi, 12-12. 